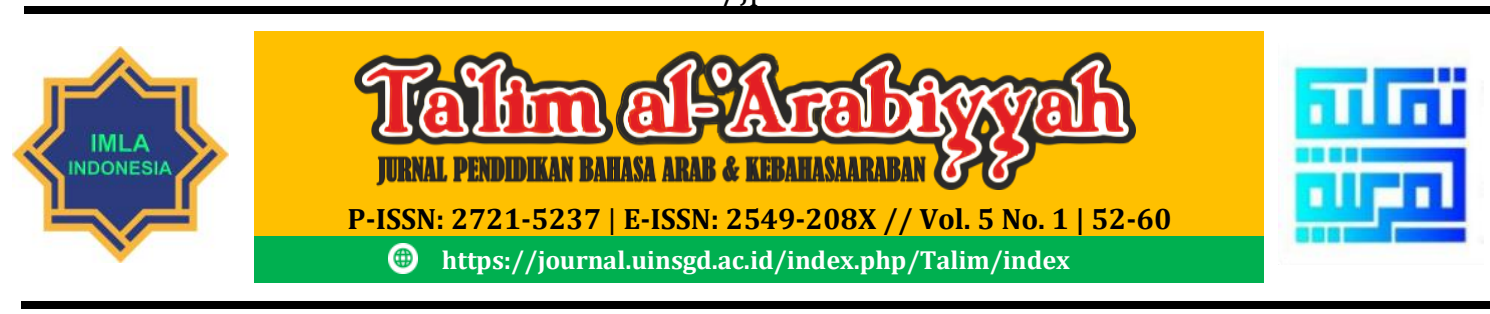

\title{
Arabic Video Lyric Untuk Meningkatkan Pemahaman Kosakata Bahasa Arab Siswa
}

\author{
Kudsiyah $^{1}$, Lailatul Mauludiyah ${ }^{2}$, Murdiono $^{3}$ \\ ${ }^{1,2,3}$ Universitas Muhammadiyah Malang \\ Corresponding E-mail: elimauludiyah@umm.ac.id
}

\begin{abstract}
Video song media was a medium that presents material in the form of text and images as well as monologue sound about the material so that students can watch and listen to videos in the learning process. The purpose of this study was to determine the effectiveness of the video song media in increasing understanding of Arabic vocabulary. This research was a quantitative research. This research was conducted at SD Muahmmadiyah $8 \mathrm{KH}$ Mas Mansur Malang. The subjects taken from this study were the VA class, which amounted to 25 students from a population of 79 students using purposive sampling technique. In this study, data collection techniques were carried out in the form of interviews, questionnaires, tests and documentation. The instrument used in the interview is the interview sheet, while the questionnaire instrument sheet is a questionnaire sheet consisting of several questions related to the video song media, the instrument sheet used in the test is a test question in the form of an interactive online game, the tests used are pretest and posttest. To find out the results of the data in this study the researcher used the $T$ test for the related sample, while to determine the effectiveness of the video media, the researcher used the N-gain formula. The collected research data is presented with descriptive statistics in the calculation of processing using SPSS 20. As for the results and testing of the hypothesis, "the video song media was effective for improving understanding of Arabic vocabulary. This is evidenced by the results obtained from the pre-test value which is smaller than the post-test value or $85.08<93.20$. Based on the output table "Paired Samples Test" it is known that the Sig. (2tailed) is $0.000<0.05$, meaning that the video song media can improve the understanding of Arabic vocabulary for the fifthgrade students of SD Muhammadiyah 8 KH Mas Mansur Malang
\end{abstract}

Keywords: Arabic Vocabulary, Learning Media, Video Songs

\section{ABSTRAK}

Media video lagu merupakan sebuah media yang menyajikan materi dalam bentuk teks dan gambar serta suara monolog tentang materi sehingga siswa dapat memperhatikan dan mendengarkan video dalam proses pembelajaran. Tujuan dari penelitian ini adalah untuk mengetahui keefektivitasan media video lagu dalam peningkatan pemahaman kosakata bahasa Arab. Penelitian ini merupakan penelitian kuantitatif. Penelitian ini dilakukan di SD Muahmmadiyah $8 \mathrm{KH}$ Mas Mansur Malang dengan subyek yang diambil dari penelitian ini adalah kelas VA yang berjumlah 25 siswa dari populasi sebanyak 79 siswa dengan menggunakan teknik puposive sampling. Dalam penelitian ini dilakukan teknik pengumpulan data berupa wawancara, 
angket, tes dan dokumentasi. Instrumen yang digunakan dalam wawancara adalah lembar wawancara, sedangkan lembar instrumen angket adalah lembar angket yang terdiri dari beberapa pertanyaan-pertanyaan terkait media video lagu, lembar istrumen yang digunakan dalam test adalah soal tes berupa game online interaktif, tes yang gunakan adalah pretest dan posttes. Untuk mengetahui hasil data dalam peneltian ini peneliti menggunakan uji $\mathrm{T}$ sampel berhubungan, sedangkan untuk mengetahui kefektivitasan media video lagu tersebut peneliti menggunakan rumus N-gain. Data hasil penelitian yang terkumpul disajikan dengan statistik deskriptif yang dalam penghitungan pengolahannya menggunakan SPSS 20. Adapaun hasil dan pengujian dari hipotesis adalah "media video lagu efektif untuk meningkatkan pemahaman kosakata bahasa Arab. Hal ini dibuktikan dengan hasil yang diperoleh dari nilai pre test lebih kecil dari nilai post test atau 85,08 < 93,20. Berdasarkan tabel output "Paired Samples Test" diketahui nilai Sig. (2tailed) adalah sebesar $0,000<0,05$, artinya, bahwa media video lagu dapat meningkatkan pemahaman kosakata bahasa Arab siswa kelas V SD Muhammadiyah 8 KH Mas Mansur Malang.

Kata Kunci: Kosakata Bahasa Arab, Media Pembelajaran, Video Lagu.

\section{INTRODUCTION}

Bahasa merupakan sarana dalam sebuah komunikasi yang sangat diperlukan untuk memenuhi kebutuhan satu sama lain. Seseorang yang belajar bahasa tidak akan terlepas dari kosakata, penguasaan kosakata merupakan hal yang sangat penting dalam berkomunikasi, tanpa penguasaan kosakata maka tujuan pembelajaran tidak akan tercapai. Lubis menyatakan (Lubis, 2018, p. 3), bahasa kosakata merupakan tanda bunyi yang disepakati untuk dapat digunakan oleh anggota kelompok masyarakat dalam berkomunikasi, bekerjasama, dan mengidentifikasi diri yang dihasilkan oleh alat ucap manusia. Bahasa juga merupakan salah satu potensi yang perlu dikembangkan sejak usia dini.

Hal yang paling penting untuk seseorang dapat menguasai keterampilan dalam berbahasa ialah penguasaan kosakata (Isnaini \& Huda, 2020, p. 2). Kosakata atau mufrodat adalah unsur yang paling penting yang perlu dikuasai oleh sesorang yang akan mempelajari suatu bahasa. Kosakata juga merupakan tulang punggung semua bahasa. Tanpa pengetahuan kosakata yang luas, maka penguasaan tata bahasa akan mengalami kegagalan dalam berkomunikasi. Di samping itu,kosakata memang membantu pelajar bahasa untuk membentuk kalimat dan mengekspresikan diri mereka dengan cara yang bermakna (Tosun, 2015, p. 642). Terdapat beberapa faktor yang terkait dengan penguasaan kosakata yaitu indikator dan tujuan, mengorganisasikan bahan, alat evaluasi, mengemas kegiatan, mengolah metode atau teknik, mencari sumber dan media pembelajaran (Isnaini \& Huda, 2020, p. 2).

Dalam proses pembelajaran terdapat dua unsur yang sangat penting yaitu metode pembelajaran dan media pembelajaran (Utami, 2020, p.186). Media pembelajaran ialah alat, metode atau teknik yang dilakukan dalam proses pembelajaran yang dapat membantu pendidik untuk menyampaikan maksud atau tujuan dari proses belajar mengajar. Hal ini menjadi tugas pendidik dalam mengemas materi pembelajar agar dapat mencapai tujuan yang diinginkan. Dalam dunia pendidikan saat ini telah terdapat beberapa aplikasi-aplikasi yang dapat digunakan sebagai multimedia pembelajaran, namun tidak semua aplikasi tersebut dapat menarik perhatian peserta didik dalam proses pembelajaran, khususnya dalam pembelajaran bahasa Arab (Arsyad, 2011, p. 24). Sementara pendapat lain tentang media pembelajaran dikatakan oleh (Wulandari, 2016, p. 4) yang menjelaskan bahwa media pembelajaran merupakan salah satu faktor yang mendukung keberhasilan proses pembelajaran di sekolah karena dapat membantu proses penyampaian informasi dari guru kepada siswa ataupun sebaliknya. Penggunaan media secara 
kreatif dapat memperlancar dan meningkatkan efesiensi pembelajaran sehingga tujuan pembelajaran dapat tercapai.

Oleh karena itu terkait beberapa masalah yang dihadapi oleh peserta didik dan pendidik dalam proses pembelajaran maka seiring perkembangan zaman, media sangat diperlukam dalam proses belajar mengajar. Salah satu upaya yang dapat dilakukan untuk meningkatkan pemahaman kosakata bahasa Arab adalah dengan diterapkannya media pembelajaran berbasis video lagu. Media video lagu (Sholihah Firdaus , 2020, p. 3) adalah media berupa video dengan modifikasi aspek suara berupa lagu dengan lirik berupa materi pelajaran yang disesuaikan.

Dari hasil wawancara yang peneliti lakukan dengan bapak Firman Alamsyah selaku guru mata pelajaran bahasa Arab di SD Muhammadiyah 8 KH Mas Mansur Malang diketahui bahwa kelemahan pembelajaran bahasa Arab adalah penguasaan kosakata (mufrodat). Salah satu faktor yang mempengaruhi keterlambatan peserta didik dalam penguasaan bahasa Arab adalah media pembelajaran yang digunakan menggunakan media powerpoint yang mana hal ini peserta didik kurang minat karena pembelajaran yang monoton dan kurang menarik minat siswa dalam proses pembelajaran kosakata bahasa Arab.

Berdasarkan permasalahan tersebut, solusi yang pernah dilakukan adalah optimalisasi pembelajaran menggunakan media video lagu yang mana hal itu juga dinyatakan oleh Rahmayanti (2014) yang diketahui bahwa penerapan media pembelajaran berbasis audiovisual efektif dalam meningkatkan penguasaan kosakata bahasa Arab. Penelitian lain juga dilakukan oleh Ni'mah (2019) yang menjelaskan bahwa media pembelajaran gubahan lagu sholawat lebih efektif dari pada menggunakan media pembelajaran konvensial dalam meningkatkan penguasaan Vocabulary "Parts Of The Bady". Penelitian lain juga di lakukan oleh Triana (2017) yang menjelaskan bahwa media lagu efektif digunakan dalam proses pembelajaran untuk meningkatkan minat dan hasil belajar peserta didik.

Berdasarkan beberapa masalah dan solusi yang pernah dilakukan, peneliti mencoba melakukan penelitian untuk meningkatkan pemahaman kosakata bahasa arab dengan menggunakan media video lagu dalam pembelajaran. Perbedaan yang peneliti lakukakan dengan peneliti sebelumnya adalah media pembelajaran yang digunakan berupa audiovisual sedangkan penelitian ini berisi tentang kosakata bahasa arab dalam bentuk video lagu. Sehingga media video lagu tersebut dapat memudahkam peneliti dalam proses pembeajaran untuk meningkatkan pemahaman kosakata bahasa Arab. Harapan peneliti media video lagu ini layak dan efektif digunakan di SD/MI sederajat.

Tujuan dari penelitain ini untuk mengetahui keefektivitasan media video lagu dalam meningkatakn pemahaman kosakata dalam pembelajaran bahasa Arab. Sedangkan kontibusi yang dilakukan adalah untuk membantu guru dalam meningkatakn mutu pembelajaran bahasa Arab di sekolah

\section{METHOD}

Jenis penelitian yang digunakan dalam penelitian ini adalah kuantitatif asosiatif. Jenis penelitian ini merupakan penelitian yang bertujuan untuk mengetahui pengaruh ataupun juga hubungan antara dua variabel atau lebih. Variabel yang digunakan dalam penelitian ini adalah variabel dependen dan variabel independen, variabel dependen dalam penelitian ini adalah kosakata bahasa Arab sedangkan variabel independen dalam penelitian ini adalah media video lagu.

Populasi yang digunakan dalam penelitian ini adalah seluruh peserta didik kelas V di SD Muhammadiyah $8 \mathrm{KH}$. Mas Mansur yang berjumlah 76 siswa. Dan sampel yang dipilih dalam penelitian ini adalah peserta didik kelas V-A di SD Muhammadiyah $8 \mathrm{KH}$ Mas Mansur yang berjumlah 25 siswa. Peneliti memilih sampel sebanyak 25 karena dilandasi oleh jumlah peserta didik yang belum mencapai 100 yaitu 76 responden. 
Dalam penelitian ini dilakukan teknik pengumpulan data berupa wawancara, angket tes dan dokumentasi. Instrumen yang digunakan dalam wawancara adalah lembar wawancara, sedangkan lembar instrumen angket adalah lembar angket yang terdiri dari beberapa pertanyaanpertanyaan terkait media video lagu. Lembar istrumen yang digunakan dalam test adalah soal tes berupa game online interaktif, tes yang gunakan adalah pretest dan posttes. Terdapat tiga teknik analisis data yang digunakan dalam penelitian ini, pertama hasil wawancara, kedua hasil angket, ketiga hasil test.

\section{RESULT AND DISCUSSION}

Dalam penelitain ini instument yang digunakan untuk mengetahui hasil belajar belajar siswa dalam pembelajaran bahasa Arab adalah dengan menggunakan wawancara.

Wawancara ini dilakukan sebelum penelitian, peneliti melakukan wawancara dengan bapak Firman Alamsyah selaku guru mata pelajaran bahasa Arab SD Muhammadiyah 8 KH Mas Mansur Malang. Dari hasil kesimpulan wawancara yang dilakukan peneliti, diketahui bahwa pertama, penggunaan media dalam pembelajaran yang masih konvensional atau monoton. Kedua, pemanfaatan media pembelajaran yang digunakan dalam proses pembelajaran yang masih kurang, pembelajaran bahasa Arab lebih sering menggunakan permaianan atau games. Ketiga, kurangnya minat peserta didik dalam pembelajaran bahasa Arab.

Sebelum melakukan sebuah penelitian, peneliti mmbuat sebuah media pembelajaran yang digunakan untuk mendukung penelitian ini adalah media video lagu. Video lagu ini dilengkapi dengan mufrodat, terjemahan mufrodat, lagu dan gambar-gambar animasi untuk memudahkan siswa dalam memahami kosakata yang telah diberikan, materi yang disajikan dalam media ini adalah mufrodat tentang pakaian (ملابس) yang peneliti berikan kepada peserta didik kelas V SD Muhamamdiyah $8 \mathrm{KH}$ Mas Mansur Malang. Tampilan materi pada media video lagu ini diperlihatkan pada gambar berikut.

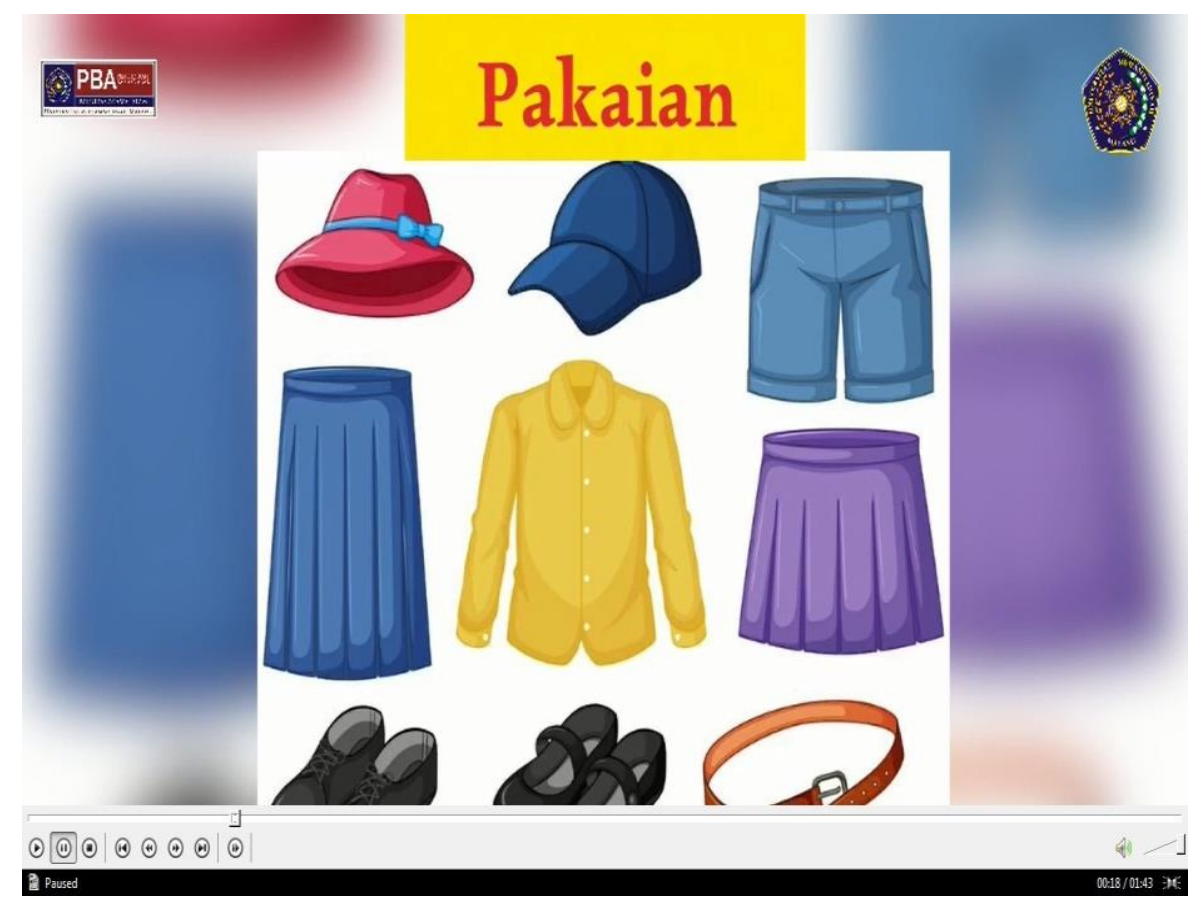

Adapun lirik lagu yang digunakan dalam video lagu ini adalah: 


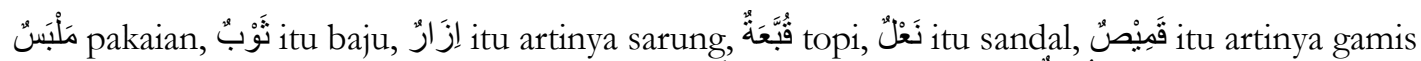

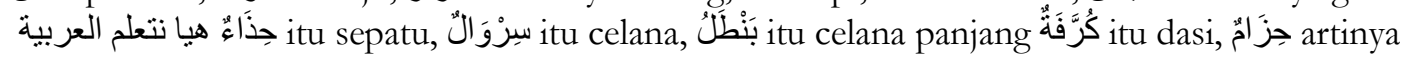
sabuk, جَوْرَبْ artinya kaos kaki, Marilah kita belajar bersama-sama.

Adapun skenario pembelajaran pada tabel 1 berikut:

Tabel 1. Skenario pembelajaran.

\begin{tabular}{|c|c|}
\hline Kegiatan & Deskripsi \\
\hline \multirow[t]{6}{*}{ Pendahuluan } & $\begin{array}{l}\text { Guru mengucapkan salam dan doa serta menanyakan kabar } \\
\text { peserta didik dengan memberikan pertanyaan }\end{array}$ \\
\hline & 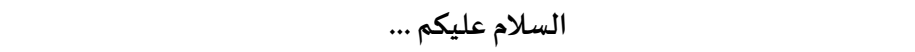 \\
\hline & كيف حالكم؟ \\
\hline & $\begin{array}{l}\text { Guru melakukan pengondisian kelas, dan melakukan ta'aruf } \\
\text { atau perkenalan }\end{array}$ \\
\hline & $\begin{array}{l}\text { Guru menyampaikan sedikit ulasan tentang materi yang akan } \\
\text { dipelajari }\end{array}$ \\
\hline & $\begin{array}{l}\text { Guru Menyampaikan tujuan pembelajaran dalam rangka } \\
\text { mencapai indikator kompetensi }\end{array}$ \\
\hline \multirow[t]{7}{*}{ Kegiatan inti } & Guru memberikan media video lagu \\
\hline & Peseta didik memperhatikan penejlasan guru \\
\hline & Guru mengulang video lagu koskata bahasa Arab \\
\hline & Guru mengajak peserta didik mengulang materi dengan \\
\hline & $\begin{array}{l}\text { bernyany1 bersama } \\
\text { Peserta didk menanvakan makna dari kosakata vang belum }\end{array}$ \\
\hline & dipahami \\
\hline & $\begin{array}{l}\text { Guru memberikan latihan soal terkait materi yang telah } \\
\text { disampaikan }\end{array}$ \\
\hline \multirow[t]{4}{*}{ penutup } & \\
\hline & Guru mengahiri proses pembelajaran dengan memberikan \\
\hline & Guru menutup pembelajran dengan membaca hamdalah, doa \\
\hline & dan memberi salam \\
\hline
\end{tabular}

Setelah diterapkannya media video lagu tersebut dalam pembelajaran, peneliti menyebarkan angket kepada seluruh responden, hal ini digunakan untuk mengetahui respon peserta didik terhadap media video lagu tersebut.

Dari hasil analisis data angket yang dilakukan peneliti terhadap peserta didik kelas V SD Muhammadiyah 8 KH Mas Mansur Malang diketahui (a), Peserta didik lebih mudah memahami kosakata bahasa Arab dengan menggunakan media video lagu. (b), Peserta didik lebih antusias dalam pembelajaran bahasa Arab apabila proses pembelajaran dilakukan dengan mengunakan media video lagu. (c), Peserta didik lebih tertarik jika pembelajaran kosakata bahasa Arab menggunakan media video lagu. (d), Peserta didik lebih mudah menghafal kosakata menggunakan lagu.

Untuk memperoleh hasil dalam evaluasi pembelajaran, maka peneliti menggunakan tes soal dalam bentuk games online interaktif, yang mana dalam tes ni peneliti memberikan tes berupa mencocokkan kata terkait materi yang telah disampaikan yaitu materi pakaian (ملابس).

Dari hasil tes ini diketahui bahwa nilai rata-rata hasil belajar peserta didik setelah diterapkannyan medai video lagu dalam pembelajaran bahasa Arab adalah sebesar 91,20 yang 
mana dapat disimpulkan bahawa hasil belajar peserta didik tersebut sudah tergolong kategori sangat baik dalam pembelajaran kosakata bahasa Arab.

Untuk menguji hipotesis, peneliti menggunakan uji t sampel berhubungan. Uji t sampel berhungan dilakukan untuk mengetahui ada tidaknya perbedaan dari hasil pretest dan posttest dari media video lagu. Sedangkan uji efektifitas adalah untuk mengetahui tingkat keefektifan media video lagu dalam proses pembelajaran yang telah dilakukan di SD Muhammadiyah $8 \mathrm{KH}$ Mas Mansur Malang.

Tabel 2. Hasil uji T sample berhubungan

\section{Paired Samples Test}

\begin{tabular}{|c|c|c|c|c|c|c|c|c|}
\hline & \multicolumn{5}{|c|}{ Paired Differences } & \multirow[t]{3}{*}{$\mathrm{T}$} & \multirow[t]{3}{*}{$\mathrm{df}$} & \multirow{3}{*}{$\begin{array}{l}\text { Sig. (2- } \\
\text { tailed) }\end{array}$} \\
\hline & \multirow[t]{2}{*}{ Mean } & \multirow[t]{2}{*}{$\begin{array}{c}\text { Std. } \\
\text { Deviatio } \\
\mathrm{n}\end{array}$} & \multirow[t]{2}{*}{$\begin{array}{l}\text { Std. } \\
\text { Error } \\
\text { Mean }\end{array}$} & \multicolumn{2}{|c|}{$\begin{array}{l}95 \% \text { Confidence } \\
\text { Interval of the } \\
\text { Difference }\end{array}$} & & & \\
\hline & & & & Lower & Upper & & & \\
\hline $\begin{array}{ll}\text { Pair } & \text { PRE-TEST - } \\
1 & \text { POST-TEST }\end{array}$ & $9.320^{-}$ & 10.483 & 2.097 & $13.647-$ & $-4.993-$ & $\begin{array}{r}- \\
4.445 \\
-\end{array}$ & 24 & .000 \\
\hline
\end{tabular}

Berdasarkan tabel output "Paired Samples Test" di atas, diketahui nilai sig (2-tailed) adalah sebesar $0,000<0,05$ artinya $\mathrm{H}_{\mathrm{a}}$ diterima dan $\mathrm{H}_{0}$ ditolak, sehingga dapat disimpulkan bahwa ada perbedaan rata-rata antara hasil belajar sebelum dan sesudah perlakuan yang artinya media video lagu dapat meningkatkan pemahaman kosakata bahasa Arab di SD Muhammadiyah $8 \mathrm{KH}$ Mas Mansur Malang.

Untuk mengetahui efektifitas media video lagu dalam meningkatkan pemahaman kosakata bahasa Arab dapat dihitung menggunakan rumus N-Gain. Sementara tingkat efektivitas yang dihitung dengan $\mathrm{n}$ gain adalah $73.50 \%$ Berdasarkan hasil skor gain maka dapat disimpulkan bahwa media video lagu efektif dalam kategori sedang yaitu 73.50\% Skor $(g)>0,70$.

Dalam proses pembelajaran, sebagai seorang pendidik maka perlu mengetahui komponenkomponen yang diperlukan dalam sebuah pembelajaran. Secara umum komponen-komponen pembelajaran dibagi menjadi enam, diantaranya adalah pendidik yang kompeten dalam bidangnya, peserta didik, bahan ajar yang digunakan, media pembelajaran, metode yang digunakan dan evaluasi (Nauri, 2019, p. 94).

Media pembelajaran adalah segala bentuk sesuatu yang mampu menyampaikan pesan atau informasi kepada penerima pesan atau informasi. Dalam proses pembelajaran sendiri media pembelajaran merupakan sumber belajar yang merupakan kombinasi antara bahan ajar (perangkat lunak) dan alat belajar (perangkat keras), sehingga pesan atau informasi dalam pembelajaran tersampaikan (Muhson, 2010, p. 2). Media adalah sesuatu alat yang dapat digunakan untuk menyampaikan pesan dari pengirim ke penerima sehingga mampu merangsang pikiran, perasaan, perhatian dan minat serta perhatian peserta didik sehingga proses pembelajaran terjadi (Liyana \& Kurniawan, 2019, p. 227). Sedangkan menurut Oemar (Arsyad, 2011, p. 45) bahwasanya media pembelajaran adalah suatu alat, metode atau teknik yang digunakan dalam pembelajaran untuk lebih mengefektifkan komunikasi antara pendidik dan peserta didik dalam proses belajar mengajar. Pendapat lain juga dijelaskan (Wati, 2019, p. 7) 
bahwa media pembelajaran adalah wadah untuk mengampaikan pesan atau materi belajar untuk mencapai tujuan dalam proses pembelajaran.

Berdasarkan beberapa definisi tentang media pembelajaran di atas dapat disimpulkan bahwa media pembelajaran adalah sarana atau cara tertentu yang digunakan seorang guru untuk menyampaikan materi pembelajaran agar siswa lebih mudah menerima dan memahami pembelajaran yang diajarkan sehingga penerima pesan (siswa) mampu memperoleh pengetahuan, keterampilan, sikap, sehingga tujuan pembelajaran dapat tercapai dengan baik

Sebagaimana menurut teori Arsyad mengemukakan bahwa belajar dengan menggunakan media audiovisual akan memberikan keuntungan lebih bagi peserta didik. Peserta didik akan dapat belajar lebih banyak dari pada jika materi pelajaran disajikan hanya dengan visual atau audio saja (Karlina, 2017, p. 29).

Dalam hal ini Sanaky dalam (Dewi \& Budiana, 2018, p. 5) menyatakan tujuan media pembelajaran adalah penyampaian materi belajar yang diberikan oleh pendidik kepada peserta didik dengan cara yang efisien sehingga dapat meningkatkan efektivitas dan kualitas hasil belajar. Sedangkan menurut Levie dalam (Hidayati, 2013, p. 5) fungsi media pembelajaran adalah alat atau perantara untuk menyampaikan materi belajar dengan cara yang mudah sehingga mampu meningkatkan minat, kualitas dan hasil belajar peserta didik. Menurut Salamon (Simbolon, Widiyowati, \& Kusumawardani, 2018, p. 24) media memiliki kemampuan menyampaikan materi melalui sistem simbol, Salomon juga menambahkan bahwa keefektivitasan media tergantung dari kesesuaian peserta didik, isi dan evaluasi. Pernyataan tersebut juga didukung oleh Anderson (Mahmudah, 2012, p. 90) yang mengatakan bahwa seoarang pendidik harus mampu memilih dan menentukan media yang akan digunakan dalam pembelajaran, media yang digunakan dalam pembelajaran harus mampu memberikan bukti yang nyata terhadap hasil belajar peserta didik.

Berdasarkan beberapa teori di atas dapat dilihat dari hasil belajar peserta didik SD Muhammadiyah 8 bahwa media pembelajaran dapat meningkatkan efektivitas belajar peserta didik dalam memahami kosakata bahasa Arab. Hal tersebut diketahui dari hasil belajar peserta didik setelah diberikanya media video lagu kosakata bahasa Arab. Selain efekif dalam pembelajaran media video lagu juga mampu meningkatkan minat belajar peserta didik di SD Muahmmadiyah $8 \mathrm{KH}$ Mas Mansur Malang, hal ini diketahui dari hasil angket yang telah peneliti berikan setelah diterapkannya media video lagu tersebut.

Menurut Stempleski \& Tomalin pembelajaran dengan menggunakan media video tidak hanya menghadapkan peserta didik pada bahasa target, tetapi juga memaparkan mereka pada aspek komunikasi non-verbal. Komunikasi non-verbal adalah terdiri dari hal-hal seperti gerak tubuh, ekspresi, postur, dan pakaian. Adapaun keuntungan yang didapat dari penggunaan media video di dalam kelas yaitu media video tentang mampu menarik minat peserta didik dan dapat mempengaruhi motivasi mereka untuk belajar (Haghverdi, 2015, p. 314).

Berdasarkan toeri para ahli di atas, hasil penelitian yang dilakukan peneliti di SD Muhamamdiyah $8 \mathrm{KH}$ Mas Mansur Malang dengan menggunakan media video lagu diketahui bahwa media video dapat meningktakan minta serta motivasi belajar peserta didik dalam pembelajaran bahasa Arab. hal ini diketahui dari antusias peserta didik dalam proses pembelajaran. Selain itu, minat belajar juga diketahui dari hasil angket yang peneliti sebarkan setelah diberikannya media media video lagu tersebut dalam pembelajaran.

Pendapat tentang teori belajar juga dijelaskan oleh Jean Piaget yang mengatakan bahwa salah satu teori belajar adalah teori belajar kognitif yang merupakan Proses belajar yang mengacu pada kemampuan akal pikiran seseorang untuk memahami suatu informasi yang menitikberatkan pada proses membangun ingatan, pengolahan informasi. Emosi dan aspek intelektual lainnya. 
Menurut Piaget perkembangan kognitif yang berlangsung melalui empat tahap, yaitu:

Tabel 3. Tahapan Perkembangan Anak

\begin{tabular}{ccc}
\hline NO & TAHAPAN & USIA \\
\hline 1 & Tahap sensori-motor & $0-1,5$ tahum \\
2 & Tahap pra-operasional & $1,5-6$ tahun \\
3 & Tahap operasional konkrit & $6-12$ tahun \\
4 & Tahap operasional formal & 12 tahun ke atas \\
\hline
\end{tabular}

Berdasarkan teori Piaget, siswa usia SD berada pada tahap operasional kongkret. Pada tahap ini, siswa mampu mengoperasionalkan berbagai logika, namun masih dalam bentuk benda-benda kongkret dan kemampuan untuk menggolong-golongkan sudah ada namun belum bisa memecahkan masalah abstrak (Ibda, 2015, p. 3).

Sebagaimanan toeri yang digunakan oleh Piaget di atas, pada penelitian ini anak sudah memasuki tahapan operasional konkrit karena dilihat dari hasil belajar siswa yang mampu mengidentifikasi kosakata yang telah diberikan sebelumnya, hal ini diketahui dari ketepatan peserta didik dalam menjawab soal yang telah diberikan.

Teoti belajar juga di jelaskan oleh R.Gagne dalam bukunya the conditional of learning 1977 sebagaimana dikutip (Ahmad Susanto, 2016, p. 2) bahwa belajar merupakan sebuah perubahan yang dapat dilihat dalam sebuah situasi belajar peserta didik. Perubahan terjadi karena adanya sebuah tindakan dalam pembelajaran.

Perubahan dalam pembelajaran ini dapat dilihat pada peserta didik kelas VA di SD Muhammadiyah KH Mas Mansur Malang yang mengalami perubahan dari hasil pembelajaran bahasa Arab setelah diterapkannya media pembelajaran berupa media video lagu kosakata bahasa Arab.

\section{SIMPULAN}

Dari hasil penelitian yang telah dilakukan di SD Muhammadiyah $8 \mathrm{KH}$ Mas Mansur Malang mengenai efektivitas media video lagu dalam meningkatkan pemahaman kosakata bahasa Arab dapat disimpulkan bahwa pembelajaran tersebut efektif dalam kategori sedang dengan presentase $73.50 \%$. Hal ini dapat diketahui dari hasil N-Gain yang menunjukkan peningkatakan hasil dalam penggunaan media video lagu untuk proses pembelajaran kosakata bahasa Arab. Peneliti berharap media video lagu ini dapat dikembangkan lagi oleh peneliti selanjurnya, serta peneliti selanjutnya mampu menggali lebih dalam beberapa referensi terkait sarana dan prasara pendidikan untuk meningkatkan keefektivitasan pembelajaran sehingga dapat menghasilkan penelitian yang lebih baik 
Ta'Cim al-'Arabiyyah : Jurnal Pendidikan Bahasa Arab dan Kebahasaaraban, 5 (1), 2021

\section{REFERENCES}

Ahmad Susanto, M. P. (2016). Teori Belajar dan Pembelajaran di Sekolah Dasar. Kencana: Jakarta.

Archambault, J., Burch, T., Crofton, M., \& McClure, A. (2008). The effect of developing kinematics concepts graphically prior to introducing algebraic problem solving techniques. Action Research required for the Master of Natural Science degree with concentration in physics.

Arsyad, A. (2011). Media Pembelajaran: Jakarta: PT Raja grafindo persada.

Dewi, P. K., \& Budiana, N. (2018). Media Pembelajaran Babasa: Aplikasi Teori Belajar dan Strategi Pengoptimalan Pembelajaran: Universitas Brawijaya Press.

Haghverdi, H. R. (2015). The effect of song and movie on high school students language achievement in Dehdasht. Procedia-Social and Behavioral Sciences, 192, 313-320. doi: https://doi.org/10.1016/j.sbspro.2015.06.045.

Hidayati, N. (2013). Analisis Penggunaan Media Pembelajaran Pada Mata Pelajaran Ekonomi Materi Akuntansi Kelas XI IPS di SMA Negeri 1 Gedangan Sidoarjo. Jurnal Pendidikan Akuntansi (JPAK), 1(3).

Ibda, F. (2015). Perkembangan kognitif: teori jean piaget. Intelektualita, 3(1).

Isnaini, N., \& Huda, N. (2020). Pengembangan Media Pembelajaran Kosakata Bahasa Arab Berbasis Permainan My Happy Route Pada Siswa Kelas Viii MTsN 10 Sleman. Al Mi'yar: Jurnal Ilmiah Pembelajaran Bahasa Arab dan Kebahasaaraban, 3(1), 1-14. doi: http://dx.doi.org/10.35931/am.v3i1.156

Karlina, H. (2017). Penggunaan Media Audio-Visual untuk Meningkatkan Kemampuan Menulis Naskah Drama. Literasi: Jurnal Bahasa dan Sastra Indonesia serta Pembelajarannya, 1(1), 2835. doi: http://dx.doi.org/10.25157/literasi.v1i1.82

Liyana, A., \& Kurniawan, M. (2019). Speaking Pyramid sebagai Media Pembelajaran Kosa Kata Bahasa Inggris Anak Usia 5-6 Tahun. Jurnal Obsesi: Jurnal Pendidikan Anak Usia Dini, 3(1), 225-232. doi: https://doi.org/10.31004/obsesi.v3i1.178

Lubis, H. Z. (2018). Metode Pengembangan Bahasa Anak Pra Sekolah. Jurnal Raudhah, 6(2). doi: http://dx.doi.org/10.30829/raudhah.v6i2.277

Mahmudah, Z. (2012). Menggugah Spirit Guru dalam Memanfaatkan Media Pembelajaran. INSANLA: Jurnal Pemikiran Alternatif Kependidikan, 17(1). doi: https://doi.org/10.24090/insania.v17i1.1490

Muhson, A. (2010). Pengembangan Media Pembelajaran Berbasis Teknologi Informasi. Jurnal Pendidikan Akuntansi Indonesia, 8(2). doi: https://doi.org/10.21831/ipai.v8i2.949

NAURI, D. N. (2019). METODE PEMBELAJARAN NAHWU PADA PONDOK PESANTREN MIFTAHUL HUDA O6 SUMBERJAYA LAMPUNG BARAT. UIN Raden Intan Lampung.

NI'MAH, K. (2019). Pengembangan Media Pembelajaran Gubahan Lagu Sholawat (Gls) Untuk Meningkatkan Penguasaan Vocabulary "Parts Of The Body". IAIN Salatiga.

Rahmayanti, S. H. (2014). Penerapan Media Audio Visual untuk. Meningkatkan Penguasaan Mufradat Pada Mata Pelajaran Bahasa Arab bagi Siswa Kelas V Sekolah Dasar Islam Terpadu al-Mishbah Sumobito Jombang. Universitas Islam Negeri Maulana Malik Ibrahim. 
Sholihah Firdaus, D. (2020). Pengembangan Media Video Lagu Model Materi Sistem Peredaran Darah Manusia Untuk Siswa Kelas V Sekolah Dasar. Jurnal Penelitian Pendidikan Guru Sekolah Dasar, 8(3).

Simbolon, A. S., Widiyowati, I. I., \& Kusumawardani, R. (2018). Pengaruh penggunaan media pembelajaran bonding board dengan model pembelajaran quantum teaching berbasis visual, auditori, kinestetik (VAK) terhadap pemahaman siswa pada materi ikatan kimia. Bivalen: Chemical Studies Journal, 1(1), 21-26. (pakai kata hlm.)

Tosun, S. (2015). The effects of blended learning on EFL students' vocabulary enhancement. Procedia-Social and Behavioral Sciences, 199, 641-647. doi: https://doi.org/10.1016/j.sbspro.2015.07.592

Triana, V. (2017). Keefektifan Media Lagu Pembelajaran terhadap Minat dan Hasil Belajar Mata Pelajaran IPA Kelas V SD Negeri Tembok Luwung 01 Adiwerna Kabupaten Tegal. Universitas Negeri Semarang.

Utami, Rizka. (2020). Ta'lìm Al-Nahw Bi Madkhal Al-Ta'allum Al-Ta'āwuñ Bi Uslūb (STAD) Bi Ma'had Dār Al-'Ulüm Al-'Ashrì Banda Aceh. Ta'lim al-'Arabiyyah: Jurnal Pendidikan Bahasa Arab dan Kebahasaaraban, 4 (2), 181-195. doi: https://doi.org/10.15575/jpba.v4i2.10092.

Wati, E. R. (2019). Ragam Media Pembelajaran. Jakarta: Kata Pena

Wulandari, D. A. N. (2016). Pengaruh Media Pembelajaran Terhadap Motivasi dan Hasil Belajar Siswa Pada Pembelajaran Kosakata Bahasa Inggris. Paradigma-Jurnal Komputer dan Informatika, 18(2), 18-24. doi: https://doi.org/10.31294/p.v18i2.1178 